concerned to find out why the GPs felt that two written communications had made so little difference to their practice.

When auditing process, unless all parties who have a direct influence on the outcome of that process are included in the audit mechanism (GPs in this case), changing performance (improving referral information) may prove elustve.

Naik \& Lee's article reinforces the need to develop both face to face multiprofessional communication and audit which crosses the percetved wall between primary and secondary care. Using such an approach, there is more chance of improved clinical practice.

Burns, T., Suvir, T., Frimbunvo, P., \& Crusp, A. (1994) General practice training for poychiatrists. Psychiatric Bulletin, 18, 286-288.

SnMon BALMER, Wakefield Healthcare, White Rose House, West Parade, Wakefield WF1 ILT

Sir: We agree with Simon Balmer. We forgot to say that a general practitioner helped to design the audit. This lapse may be an example of the partly unconscious barriers that Simon Balmer describes. We do meet and talk fairly often with our GPs. We avoided mentioning the items we were measuring in the interests of science. More recently we have often suggested letters might be sent to the base, and might include more information, but most still arrive after some delay, at the hospital, and some are still highly condensed. Old habits may die hard, espectally in the face of modern pressures. However, Simon Balmer's reminder to include all parties that affect outcomes in the audit process is very well taken.

ALAN LEE, Universtty Hospital, Nottingham NE7 2UH; and PRAKASH NAIK, Lyndon Resource Centre, Hobs Meadow, Solihull, West Midlands B92 8PW

\section{Buddhist meditation}

Sir: Dr Dwivedi gives an interesting account of the relationship between Buddhist meditation and contemporary psychotherapy (Psychiatric Bulletin, 1994, 18, 503-504). However I think he gives an overly negattve impression of Buddhism. He describes the five precepts in their negattve form for example refraining from stealing and lying. In their positive form these are practising generosity and truthfulness. The cultivation of these posittve counterparts are probably a more important focus for those who wish to practise Buddhist ethics.

As well as meditation on breathing the Buddha taught the 'metta bhavana' or development of loving lindness (Metta Sutta, 1985). The cultivation of metta provides an emotionally posittve balance to the meditation on breathing. Dr Dwivedi refers to the famous analogy with the ocean: Just as the ocean has one taste the taste of salt so the Buddhist teaching has not the taste of renunciation, but rather the taste of vimuttl, which is release, or freedom (Udana, verse 56, 1985), Renunclation is an aspect of the Buddhist path, but the purpose is to find freedom, especially freedom from suffering.

The importance of understanding the positive nature of Buddhism is threefold. First many Westerners may have a materialistic, nihilistic conditioning which will tend to lead to a misinterpretation of Buddhism as a nihilistic (and therefore unattractive) religion. Secondly, the meditation on breathing practlsed on its own without also cultivating posittve emotions can lead to adverse psychological effects. In particular, it may lead to an exaggeration of neurotic defences such as intellectualisation and reaction formation to dissociate from egodystonic emotions (Epstein \& Leif, 1981). Thirdly, in order to gain 'insight' not only is a concentrated mind required but also one flexible and refined through being 'soaked' in emotional posittuity (thana). The final goal of enlightenment includes wisdom (panna) which is conjoined with compassion (karuna) to help other sentient beings.

EPSTERN, M. \& LETr, J. D. (1981) Psychiatric complications of meditation practice. Journal of Transpersonal Psychology. 13. 137-147.

Metta Sutta. In Sutta-Nipata. Translation by Saddhatissa, $H$. (1985) London: Curzon.

Udana. Verses of Upuft. In The Mtnor Anthologles of the Pall Canon, Part II. Translation by Woodwand, F.L. (1985) London: Pall Text Society.

PARAMABANDHU Groves, National Addiction Centre, Addiction Sclences Bullding, 4 Windsor Walk, London SE5 8AF

Sir: Thank you for asking me to respond to Dr Groves' letter. Buddha taught many techniques of meditation and suited his teachings to the needs of the individuals. As 
practice of Brahma Viharas to many so that they could develop qualities of loving kindness (Metta), compassion (Karuna), sympathetic joy (Mudita), and equanimity (Upekkha). A degree of mental purification through other meditative practices makes it easier to develop Brahma Viharas. On the other hand the practice of Brahma Viharas meditation prepares oneself for practising samadhi (continuous concentration of mind e.g. through 'anapan' which uses breath as the subject for meditation).

Development of morality can similarly be at different levels. At the most basic level, it means refraining from harmful speech and actions. At higher levels, it involves cultivating the posittve aspects of morality in its more and more subtle forms.

K. N. Dwived, Child \& Family Consultation Service, 8 Notre Dame Mews, Northampton NN1 2BG

\section{Prend's sirters}

Sir: That four of Sigmund Freud's five sisters perished in Naxd death camps during the Holocaust (Gillbert, 1987, p. 476) is not widely known. Rosa, aged 84 years, died in Auschwitz, Marie (82) and Pauline (80) met their deaths in Treblinka, and Adolfine (81) was murdered in Theresienstadt. Freud left Vienna for Hampstead in 1938, succumbing to cancer of the jaw shortly after.

Gnamer, M. (1987) The Holocaust. Glaggow: Fontana/ Collins.

BrinN O'ShIE, Newcastle Hospital, Greystones, Country Wicklow, Ireland

\section{Label of personality disorder}

Sir: Regarding the 'label of personality disorder' (Mulligan, Psychiatric Bulletin, 1994, 18, 512-513) which is so unpopular with patients, my practice is to use the term 'personality difficulties'. Patients are much more accepting of this and helpful discussion of individual difficulties can occur rather than patients (understandably) defending themselves against the label of another 'disorder'.

Phmip STradman, Sutton Hospttal, Sutton (St George's rotation) 